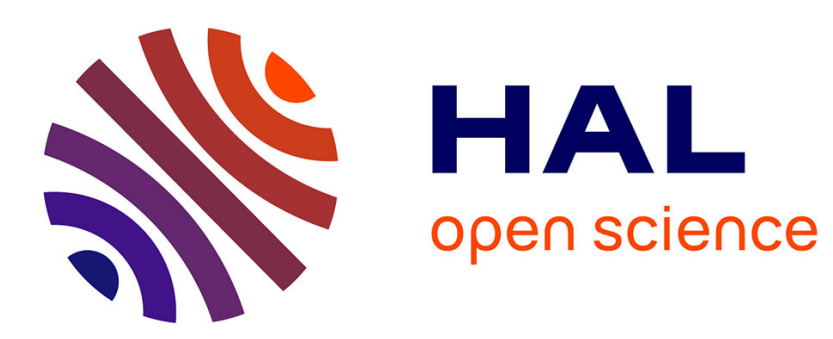

\title{
The Rise of Populist Movements in Europe: A Response to European Ordoliberalism?
}

David Cayla

\section{To cite this version:}

David Cayla. The Rise of Populist Movements in Europe: A Response to European Ordoliberalism?. Journal of Economic Issues, 2019, 53 (2), pp.355-362. 10.1080/00213624.2019.1594510 . halshs02128366

\section{HAL Id: halshs-02128366 \\ https://shs.hal.science/halshs-02128366}

Submitted on 14 May 2019

HAL is a multi-disciplinary open access archive for the deposit and dissemination of scientific research documents, whether they are published or not. The documents may come from teaching and research institutions in France or abroad, or from public or private research centers.
L'archive ouverte pluridisciplinaire HAL, est destinée au dépôt et à la diffusion de documents scientifiques de niveau recherche, publiés ou non, émanant des établissements d'enseignement et de recherche français ou étrangers, des laboratoires publics ou privés.

\section{(ㅇ)(1) $\$$}

Distributed under a Creative Commons Attribution - NonCommercial - NoDerivatives 44.0 


\section{The Rise of Populist Movements in Europe: A Response to European Ordoliberalism?}

David Cayla, University of Angers, Granem

Political specialists agree that contemporary times are marked by the "return of populist forces", a return that is considered to be the fourth wave of such forces (Badie 2018). The current rise of populism is a global phenomenon. Badie and Vidal (2018) count that between 2014 and early 2018, 33 countries in the world had populist forces that were either part of a ruling coalition or at the head of governments. Western and Central Europe appear to be ahead of this emergence, since 15 out of the 33 countries were from this region, 11 being from the European Union.

According to Polanyi's (1944) double movement framework, the emergence of populist forces may be understood as a response to the globalization process and more especially to the financial and economic crisis of 2008-2009. Indeed, after a short period of Keynisanism, most countries turned toward the reestablishment of "financial market trust" by implementing so-called "consolidation policies" aiming to reduce public debts and deficits, to narrow state intervention and to dismantle institutional regulations of market forces. Such policies have important social consequences and may inflict what Polanyi (1944) call "the lethal injury to the institutions in which his social existence is embodied" (p. 164). The rise of populism could therefore be understood as a consequence of this injury. Brutalized by pro-market policies, societies would call for the cure of wounded institutions by rejecting the traditional political forces, identified as the main threat for social institutions.

But what exactly is populism and what does it stand for? In a short paper, Marc Lazar (2018) argues that left-wing and right-wing populism, although having "undeniable common features" (p. 123) such as rejecting ruling classes, opposing globalization process, contesting some aspects of liberal democracies, cannot be assimilated. They do not share the same definition of people; they don't praise the same policies towards migrants; they are opposed in international policies; they don't share the same voters. Moreover, economist Thomas Coutrot (2018) judges that most countries that have been recently ruled by populist leaders don't propose any economic policies that would be in coherence with what should be their fundamental doctrine: "A consistent populist politician should, in theory, implement a growth policy that would be at the same time redistributive, to favor the people unity, and self-centered, to reduce the national dependency toward foreign markets" (p. 111).

Overall, it seems difficult to define clearly what would be a populist ideology. Maybe populism doesn't come up to carry new political projects but to restore the wounded social institutions. This would mean the very nature of populism lies in its conservative aspects, as part of the Polanyian "countermovement" process. Therefore, since societies are different and react differently to neoliberal policies, the institutions to be rebuilt may be different from a society to another.

Although populist movements differ, it doesn't mean that they do not respond to the same fundamental causes. Behind this variety, interesting dynamics may draw the future of political conflicts and debates. From this aspect, European populism must be studied with a special attention. The 
sudden rise of populism in one of the wealthiest region of the world is by itself a challenging question. Another interesting side of European populism concerns its economic motivation. In a recent Wall Street Journal article, journalist Eric Sylver (2018) argues that both European right-wing and left-wing populisms praise for public intervention in economics: "Their common target is the technocratic consensus of Europe's broadly centrist mainstream parties that the continent needs to privatize, deregulate, limit social protections, boost competition and let in foreign capital in order to grow." At last, European populism insists on valuing national institutions over the European supranational framework.

European populism is an emergent and an ambiguous political movement. Indeed, Hungarian Prime minister Viktor Orbán and Spanish Podemos leader Pablo Iglesias Turrión have very few in common. But populisms appear to carry dynamic and flexible forces that may take unexpected paths. The recent French "Yellow Jackets" protest that appeared in the late 2018 may help to understand the way a populist movement can rapidly evolve. During the early demonstrations, the main demand of protesters was to reduce gasoline taxes; soon it evolved into fiscal justice; in the last demonstrations, Yellow Jackets protesters were claiming for a renewal of democracy and for the establishment of a citizens' initiative referendum.

According to Polanyi (1933), capitalism and democracy are fundamentally contradictory. This contradiction explains why implementing a system of self-adjusting markets is utopic: "it would have physically destroyed man and transformed his surroundings into a wilderness" says Polanyi (1944, p. 3). Therefore, the society as a whole must enter into resistance. This may lead to only two solutions: either the self-adjusting markets must be controlled by social institutions, but it would mean the end of free markets and therefore capitalism, or the social resistance must be subdue, but this implies the end of democracy.

If it is believed that European populisms can be assimilated as a Polanyian countermovement and if its dynamics is to solve the fundamental contradiction between democracy and capitalism, the question that is to be considered is to know which one of the two "solutions" the populists will contribute to reinforce. Another question is to understand the specific nature of the European Union and the reason why it is a central target for European populisms.

\section{The specificity of the European economic crisis}

Although the 2008-2009 crisis started with the collapse of the American subprime mortgage credit system, the European Union economy has been more severely impacted than the American economy since the American real GDP was $20.8 \%$ higher at 2018 third quarter compared to January $1^{\text {st }} 2007$, whereas the European Union GDP was only $13.0 \%$ higher. ${ }^{1}$

Some reasons are often proposed to explain this gap. The first one is the difference between economic policies from both sides of the Atlantic. Whereas the Obama administration and the Federal Reserve were implementing a full Keynesian economic policy, with very low interest rates, the Federal Reserve quantitative easing and public deficits above 10\% of GDP from 2009 to 2011, the European Union countries implement only a partial Keynesian policy. For instance national public deficits never reached $6 \%$ of GDP in average, and the European Union institutions asked for their reduction as soon as 2010. 
The second one is due to the 2010-2013 public debt crisis. The rise of interest rates in many peripheral countries (Southern Europe, but also Ireland and many Central Europe countries) pushed many national economies into a greater crisis and explains the inability of the European Union to maintain Keynesian policies.

The real causes of the euro crisis are still in dispute. For European authorities, the affected countries had dysfunctional institutions. For this reason they advocated for economic policies aiming to correct these imperfections by reforming their national institutions in a move towards a balanced budget and improved competitiveness (that implies lower wages and more flexibility of the labor market).

There is however another explanation of the euro crisis. By organizing the European economy according to the principles of free competition and by promoting the circulation of mobile production factors, the Single Market has strengthened the agglomeration mechanisms, which has led to a European industrial polarization (Cayla 2018). Although this dynamic has been beneficial for the core European countries, it has accelerated the deindustrialization of peripheral economies.

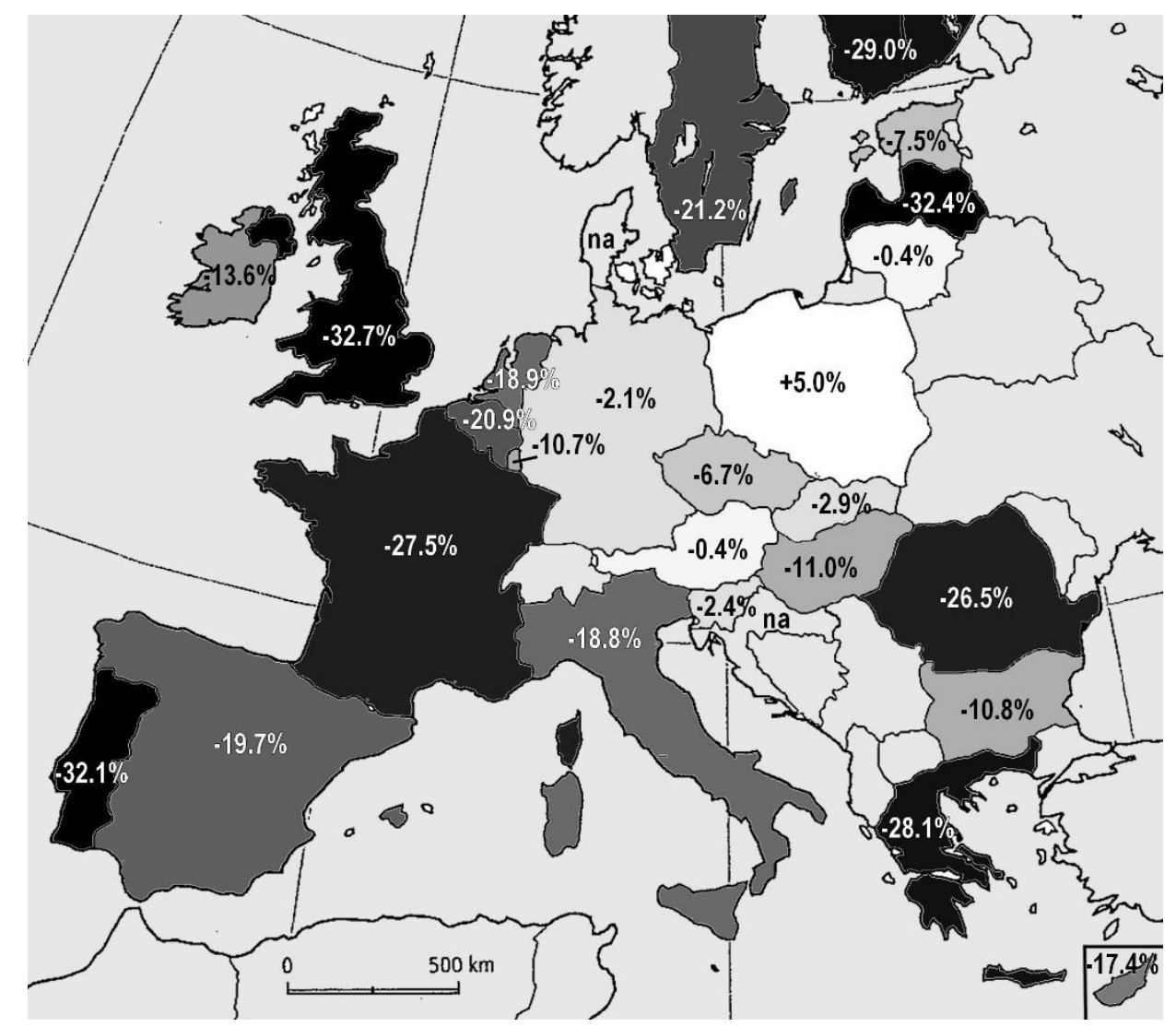

Fig. 1: Change in industrial employment from 2000 to 2017 in $\%^{2}$

Figure 1 can be explained as a classic effect of industrial agglomeration (Krugman 1991). As a matter of fact, European countries don't share the same geographical advantages. Germany and Austria benefit from a long history of industrial development that started with the second industrial revolution marked by the transportation revolution and the development of greater production units. This industrial history helped these countries to develop specific infrastructures (such as transportation facilities, especially fluvial shipping and harbors) and institutions (such as technical education, specific work organizations and trade union joint management ...). These infrastructures and institutions can 
be seen as specific territorial production factors since they are deeply embedded in territories and in specific cultural features. Moreover, they are specifically adapted to industrial production.

Until the end of the 1980s, German territorial industrial advantages didn't prevent other European countries to progress and develop their own industrial production. The European Common Market that allowed free circulation of goods increased the potential outlets of every European economies and the German structural competitive advantages could be solved by currency devaluation from less competitive countries such as France or Italy. According to Wendy Carlin (1996), the average annual industrial growth even appeared to be higher in France (7.3\%) and Italy (6.9\%) than in West Germany (5.1\%) between 1961 and 1973.

Two important events transformed radically the European economy from a cooperative organization that allowed mutual growth into a competitive system ruled by national rivalries. The first event has been the signature of the Single European Act in 1986. By creating the European Single Market and by adopting the principle of the "four freedoms", the European leaders added to the free circulation of goods and services the free circulation of labor and capital. Labor, of course, has not been totally released because of cultural and languages barriers and of the difficulty for workers to adjust themselves to different national social systems. Capital, however, was fully released, especially after the creation of the European currency union in 1999. With the euro, nothing could prevent savings from a country to be invested into productive capital into another country.

The second important event was the fall of the Communist Bloc in the early 1990s and the integration of Central Europe countries into the European Union in 2004. Workers from these countries were a godsend for German and Austrian manufacturers. Cheap and well trained, they were able to bring, after a time of necessary investments, another territorial advantage to adjacent wealthier countries. As Guillaume Duval (2013) explained, German and Austrian industrial producers were able to outsource their low value production into former socialist countries were wages were much lowers.

Figure 1 can now be fully explained. After the release of capital movements in Europe and because of the specific territorial production factors, industrial investments went in priority where they were the most profitable, in the core European countries, instead of the peripheral states where there was no territorial advantages.

This industrial dynamic is a major explanation of the euro crisis that appeared in the peripheral countries. Because they were unable to develop their industrial production, these countries had to face deficits in their trade and current account balances. On the contrary, as shown in figure 2, core European countries where able to develop surplus used to respond to the financial needs of peripheral countries. 


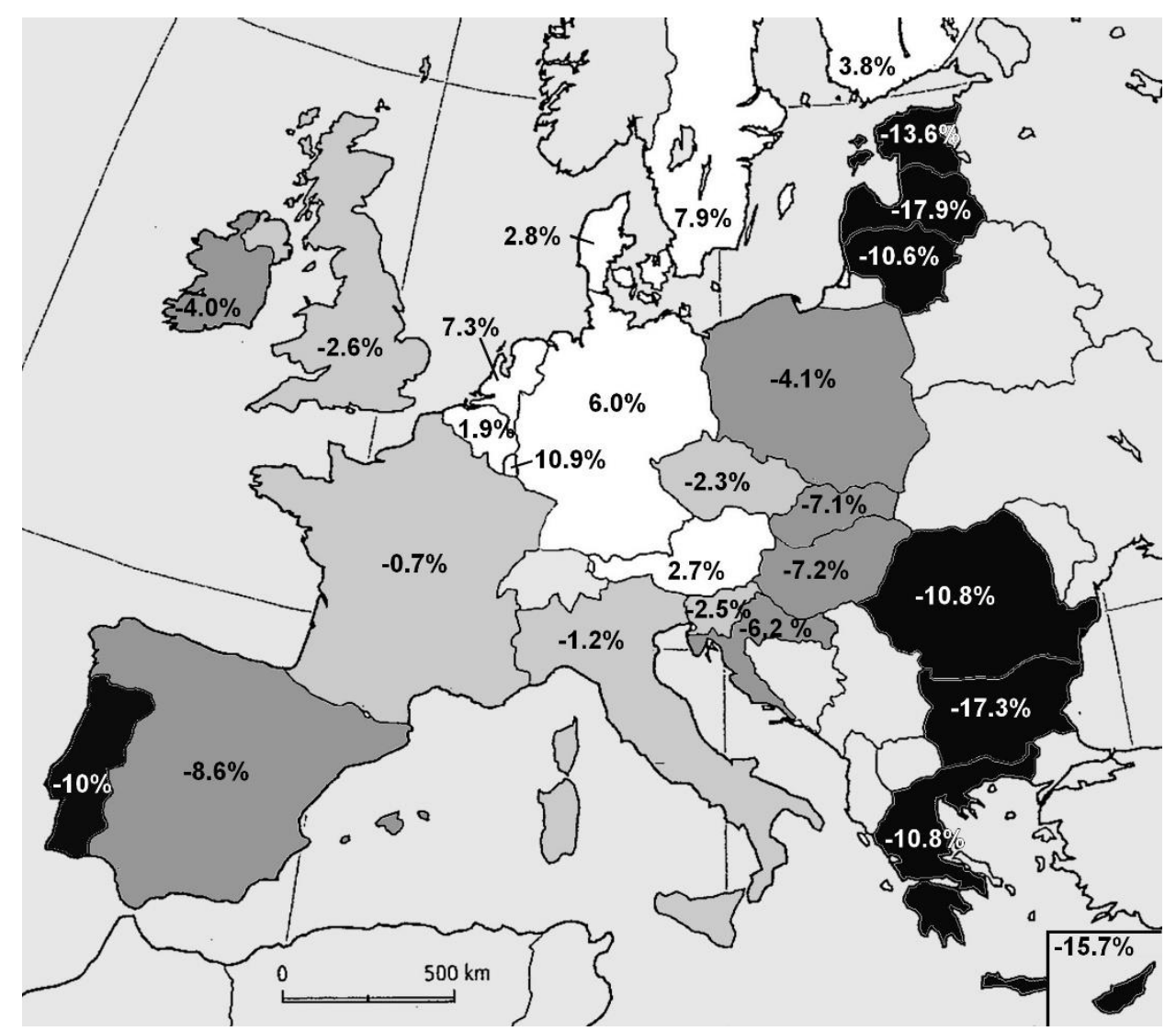

Fig. 2: European current account balances in \% of GDP (average 2005-2007) ${ }^{3}$

\section{The democratic trap of the European institutions and its consequences}

The economic collapse of peripheral countries after 2010 is as well the consequence of economic imbalances as it is of a rigid European institutional architecture.

In a very stimulating book, Wolfgang Streeck (2014) argues the current European architecture is similar to the one imagined by Friedrich Hayek (1939). Streeck emphasizes that Hayekian economic federation is conceived in order to prevent any national or federal economic intervention. Because they find themselves mutually in competition, national states cannot take any action that would not fit the capitalist class interests. If they were doing so, investments would flee the country and its population would face unemployment and decreasing incomes. At the same time, Hayek argues that federal economic intervention must also be ruled out, for the federation may not have the political legitimacy to favor a specific state over the others. Moreover, this federation would be liberal and praise for fair competition in order to be accepted by the different nations. Overall, Hayek believes that "the federation will have to possess the negative power of preventing the individual state for interfering with economic activities in certain ways, also it may not have the positive power of acting in their stead" (1939, p. 12). This "international government" would then be "limited to an essentially liberal program" (1939, p. 16).

The creation of the euro and the Single European Market achieved rather perfectly the Hayekian program. 
Indeed, the way the European economy is regulated is a direct product of the ordoliberal philosophy stating that public intervention should only concern the legal system surrounding the markets without any discretionary intervention. But by detaching the economic sphere from the reach of national societies, this process created a European economy with no real European society to control it. This process created an economic dynamic that appeared to be destructive for national institutions without affecting every country the same way.

To make this unfairness politically acceptable, "market justice" has replaced "social justice" as the dominant value in the European Union (Streeck 2014). What is considered to be fair is the outcome of a free competition between individual agents or national states, whereas politic decisions such as the opportunity to cancel the Greek public debt would always be suspected to be the result of a corrupted political bargaining.

Competition between European countries has plunged them into a perpetual bid system in order to obtain investments from transnational firms. Since they are not allowed to restrain the circulation of labor and capital in the Singlet Market, European states must therefore lower the taxes on mobile resources, especially capital. As a consequence, governments have to obey to the needs of markets, especially financial markets, since they became what Streeck calls "debtor States", countries that need to keep the trust from financial investors in order to borrow at low interests.

Competition between individual Europeans has a similar consequences. From Eastern to Western Europe and from the Southern to the Northern countries, labor forces move according to the need of the European labor market. Because of higher wages in the West, Eastern and Central Europe countries lost hundreds of thousands of their citizens. Since the Eurozone crisis, it is now the turn of Southern countries to lose important parts of their youth, especially the most educated who are pushed to flee unemployment.

\begin{tabular}{|l|c|l|l|l|r|}
\hline \multicolumn{2}{|c|}{$\begin{array}{c}\text { Eastern countries migration } \\
\text { losses (2000-2017) }\end{array}$} & \multicolumn{2}{|c|}{$\begin{array}{l}\text { Western peripheral countries } \\
\text { migration losses (2010-2017) }\end{array}$} & \multicolumn{2}{c|}{$\begin{array}{c}\text { Core European countries } \\
\text { migration gains (2010-2017) }\end{array}$} \\
\hline Bulgaria & -421000 & Greece & -234654 & Germany & +3963353 \\
\hline Romania & -2071357 & Spain & -104561 & Netherlands & +346165 \\
\hline Poland & -207172 & Portugal & -137958 & Austria & +451984 \\
\hline Baltic states & -819114 & Ireland & -24405 & Belgium & +383358 \\
\hline
\end{tabular}

Table 1: net migrations gain and losses in some European countries ${ }^{4}$

\section{What aim European populisms? A possible answer}

In a rather pessimist book, Ivan Krastev (2017) explains the crisis of liberal democracy in central Europe as a consequence of the fading of meritocratic values. With the free circulation of labor, the most educated people (the meritocratic elite) are seen as trying to escape their national obligations, seeking into the Western countries an individual happiness that common folks can't obtain. For Kratev, the rise of populism in these countries can therefore be interpreted as a response to the idea of free circulation 
of people. It also explains why the migratory crisis of 2015-2016 was such a political issue in those countries, although they were not directly confronted with a massive arrival of migrants.

In Southern Europe, the Syriza administration of 2015, the Legua-Cinque Stelle coalition in 2018 as well as the rise of Podemos in Spain since 2014 or the victory of a left-wing coalition in Portugal in 2015 can all be interpreted as a response to the technocratic governance imposed by the European institutions during and after the Eurozone crisis. The idea of a perpetual financial consolidation process that would only aim to regain the trust of financial markets is politically unacceptable.

It may be too soon to discuss about the French Yellow Jacket protest, but it is significant to observe that one of the main claims of protestors were for fiscal justice. The early Emmanuel Macron decision to suppress the wealth tax has been considered unfair since middle class and consumption taxation were increasing at the same moment.

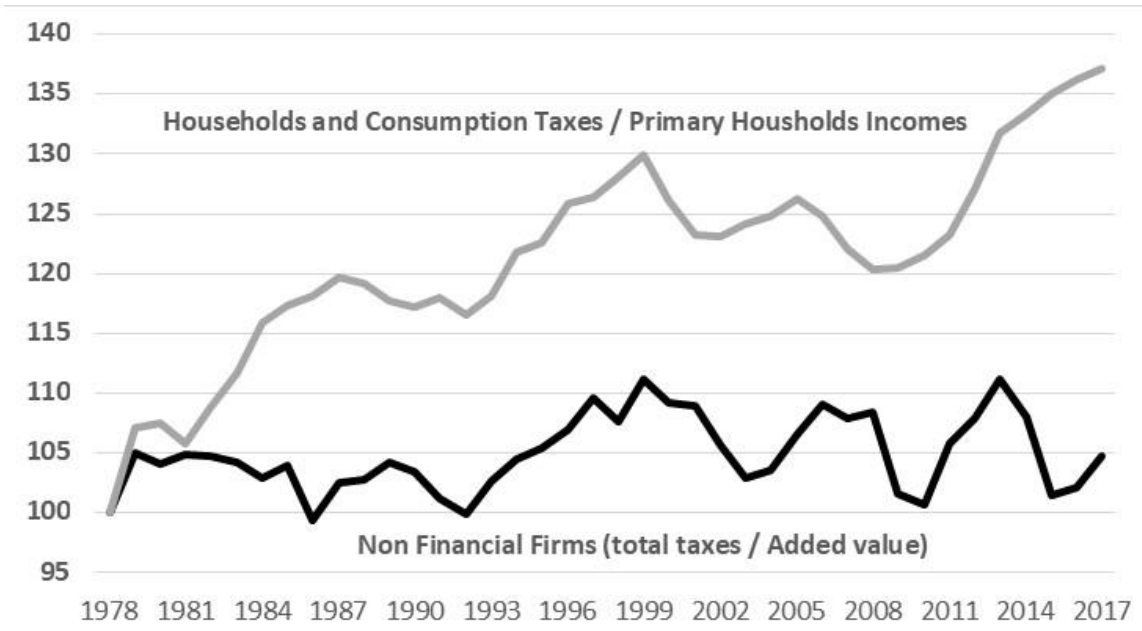

Figure 3: comparative evolution of firms and household taxation in France (1978-2017) ${ }^{5}$

This evolution of taxes has a specific meaning. Like many other European countries, French economic policy follows a strategy based on the development of a fiscal attractiveness. Since the financial crises, it clearly appears that taxes on households and consumption increase more rapidly than taxes on firms as the latest are considered to be mobile (figure 3).

Overall, a common feature in every populist movements can be found. Central European populisms praise for equality between educated people that enjoy free movement across the continent and common people who are attached to their national territory; southern populisms claims an equal dignity between the countries that became the losers of the industrial polarization process and the core European countries that manage on the contrary to attract capital; at last, French populism can be understood as a demand for fiscal equality between the mobile and the non-mobile people and resources.

As it is organized, the European Single Market institutions can be seen as a specific attempt to solve the Polanyi contradiction between democracy and capitalism by instituting a sort of fake democracy. European populisms affect this attempt by insuring a move toward a demand for equality and a "true" democracy. An ideal that seems to be clearly preferred to capitalism and free competitive markets. 


\section{Notes}

1. OECD (2018), Quarterly GDP (indicator). doi: 10.1787/b86d1fc8-en (Accessed on December 16th 2018).

2. Eurostat (2018), volume of work done (hours worked) in manufacturing. (Accessed on 12 December 2018.)

3. Eurostat (2018). (Accessed on December 12th 2018.)

4. Source : Eurostat (2018), net migration plus statistical adjustements. (Accessed on December 17th 2018.)

5. Source : Insee (2018). (Accessed on December 7th 2018.)

\section{References}

Carlin, W. (1996). "West German growth and institutions, 1945-90". In N. Crafts \& G. Toniolo (Eds.), Economic Growth in Europe since 1945 (pp. 455-497). Cambridge: Cambridge University Press. doi:10.1017/CBO9780511758683.016

Krastev, Ivan (2017), After Europe, Penn University Press.

Badie, Bertrand and Dominique Vidal (2018), Le retour des populismes, L'Etat du monde 2019, La Découverte, Paris.

Badie, Bertrand (2018), "Introduction. L' " éternel retour " ?", in Badie, Bertrand and Dominique Vidal (2018), Le retour des populismes, L’Etat du monde 2019, La Découverte, Paris, pp. 9-22.

Cayla, David (2019), “Crise de l'euro et divergences économiques : les conséquences du marché unique pour l'unité européenne", in La Constitution matérielle de l'Europe, edited by Céline Jouin, pp. 187211, Pédone, Paris.

Coutrot, Thomas (2018), "Existe-t-il une politique économique populiste ?" in Badie, Bertrand and Dominique Vidal (2018), Le retour des populismes, L'Etat du monde 2019, La Découverte, Paris, pp. 110-117.

Duval, Guillaume (2013) Made in Germany : Le modèle allemande au-delà des mythes, Paris, Le Seuil. Hayek, Friedrich (1939), "The Economic Conditions of Interstate Federalism", New Commonwealth Quarterly, V, No 2, pp. 131-49.

Krugman, Paul (1991), Geography and Trade, MIT Press.

Lazar, Marc (2018), "Populismes de droite, populismes de gauche en Europe", in Badie, Bertrand and Dominique Vidal (2018), Le retour des populismes, L'Etat du monde 2019, La Découverte, Paris, pp. 118-125.

Polanyi, Karl (1935), "The essence of fascism", in John Lewis, Karl Polanyi and Donald K. Kitchin, Christianity and Social Revolution, pp. 359-394. 
Polanyi, Karl (2001) [1944], The Great Transformation: the political and economic origins of our time, Beacon Press, Boston.

Streeck, Wolfgang (2014), Buying time: The Delayed Crisis of Democratic Capitalism, Verso Books.

Eric Sylver (2018), "Europe's Populist Left and Right Share a Common Call: State intervention", The Wall Street Journal, 12-14-2018. 